\title{
Kontribusi komunikasi dan keterampilan manajemen konflik kepala sekolah terhadap kinerja guru
}

\author{
Syaifulloh Nugroho * \\ Program Studi Pendidikan Dasar, Universtas Negeri Yogyakarta. \\ Jalan Colombo No. 1, Karang Malang, Depok, Sleman, Yogyakarta 55281, Indonesia. \\ syaifullohnugroho@gmail.com \\ * Corresponding Author
}

\section{ARTICLE INFO}

\section{Article History \\ Received: \\ 8 May 2019; \\ Revised: \\ 10 February 2020; \\ Accepted: \\ 10 February 2020}

\section{Keywords}

Komunikasi kepala sekolah;

Manajemen konflik;

Kinerja guru;

Principal

communication skill;

Conflict management

skill;

Teacher's performance

\begin{abstract}
ABSTRAK
Penelitian ini bertujuan untuk: 1.) Mengetahui kontribusi komunikasi kepala sekolah terhadap kinerja guru; 2.) Mengetahui kontribusi keterampilan manajemen konflik kepala sekolah terhadap kinerja guru; dan 3.) Mengetahui kontribusi komunikasi dan keterampilan manajemen konflik kepala sekolah terhadap kinerja guru di Sekolah Dasar Negeri di Kecamatan Mlati, Kabupaten Sleman, Daerah Istimewa Yogyakarta. Penelitian ini menggunakan jenis expostfacto dengan pendekatan kuantitatif. Populasi penelitian ini adalah seluruh guru di SD Negeri Kecamatan Mlati, Kabupaten Sleman, Daerah Istimewa Yogyakarta pada tahun ajaran 2017/2018. Teknik pengambilan data yang digunakan adalah angket. Teknik analisis data menggunakan regresi sederhana dan regresi ganda. Hasil penelitian ini menunjukkan bahwa terdapat kontribusi komunikasi dan keterampilan manajemen konflik kepala sekolah terhadap kinerja guru SD Negeri di Kecamatan Mlati, Kabupaten Sleman, Daerah Istimewa Yogyakarta. Kontribusi komunikasi kepala sekolah terhadap kinerja guru adalah sebesar $64,9 \%$, kontribusi keterampilan manajemen konflik kepala sekolah terhadap kinerja guru adalah sebesar $80,6 \%$, dan kontribusi komunikasi dan keterampilan manajemen konflik kepala sekolah terhadap kinerja guru adalah sebesar 85,8\%.
\end{abstract}

This research aims to: 1.) Knowing the contribution of communication made by the headmaster to teacher performance; 2.) Knowing the contribution of headmaster conflict management skills to teacher performance, and 3.) Knowing the contribution of communication and conflict management skills by the headmaster to the performance of teachers in Primary Schools in Mlati District, Sleman Regency, Special Region of Yogyakarta. This study uses a post-facto type with a quantitative approach. The study population was all teachers at the Primary School in Mlati District, Sleman Regency, Special Region of Yogyakarta in the academic year 2017/2018. Data collection techniques using a questionnaire. Data analysis techniques using simple regression and multiple regression. The results of this study indicate that there is a contribution of communication and conflict management skills made by the principal to the performance of elementary school teachers in the Mlati District, Sleman Regency, Special Region of Yogyakarta. The contribution of communication made by the headmaster to teacher performance was $64.9 \%$, the contribution of conflict management skills made by the headmaster to teacher performance was $80.6 \%$, and the contribution of communication and conflict management skills made by the headmaster to performance the teacher is $85.8 \%$.

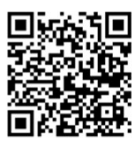

This is an open access article under the CC-BY-SA license.

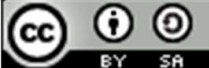




\section{PENDAHULUAN}

Pendidikan nasional hakekatnya bertujuan untuk meningkatkan kualitas masyarakat Indonesia menjadi lebih baik, maju dan modern. Keberhasilan pendidikan nasional tergantung pada sarana dan sumber daya manusia yang memadai. baik sarana dan sumber daya manusia maka semakin cepat tujuan pendidikan nasional tercapai. Pendidikan yang berkualitas akan menghasilkan output yang diharapkan sehingga dapat meningkatkan kesejahteraan bangsa Indonesia. Sekolah berperan sebagai salah satu organisasi atau lembaga pendidikan yang ditujukan untuk mencetak generasi-generasi unggul dalam mencapai tujuan pendidikan nasional. Sekolah adalah organisasi yang mengelola berbagai sumber daya yang ada seperti: kurikulum, tenaga pendidik, sarana prasarana maupun sumber daya lainnya. Sekolah yang bermutu dapat dilihat dari kemampuan sumber daya manusia yang mengelola lembaga tersebut.

Guru merupakan komponen sumber daya manusia yang berperan untuk mencapai tujuan pendidikan nasional di sekolah. Salah satu faktor tinggi rendahnya kualitas pendidikan di sekolah sangat ditentukan oleh kinerja guru. Semakin baik kinerja guru semakin cepat pula tercapainya tujuan pendidikan nasional. Berkembangnya sistem pendidikan dan semakin kompleksnya tantangan yang dihadapi guru secara individu maupun profesi guru secara keseluruhan memiliki kepentingan yang sangat besar bagi pembangunan bangsa Indonesia di masa depan. Pemberdayaan dan pengembangan kompetensi guru di sekolah tidak dapat dilepaskan dari kondisi atau suasana ling- kungan yang ada di dalam sebuah orga- nisasi tersebut. Suasana yang nyaman akan sangat mendukung orang untuk dapat me- ngembangkan potensinya.

Indonesia merupakan negara yang memiliki jumlah guru yang banyak. Meskipun mempunyai tenaga guru yang banyak, tetapi kinerja guru di sekolah belum maksimal. Pada kenyataannya, Indonesia belum sepenuhnya menghasilkan guru yang profesional dan bermutu. Padahal semua komponen dalam proses belajar- mengajar, materi, media, sarana dan prasarana tidak memberikan dukungan yang maksimal tanpa adanya guru (Pandoyo \& Wuradji, 2015, p. 252). Hal ini membuktikan bahwa kinerja guru masih tergolong cukup rendah dalam melaksanakan proses pembelajaran. Masih banyak di temukan guru yang mempunyai sertifikat pendidik, namun pada kenyataannya masih sering meninggalkan siswa pada jam pelajaran untuk mengurus persyaratan sertifikasi. Tugas pokok sebagai pengajar tidak dilakukan dengan baik di sekolah. Peristiwa tersebut tidak hanya terjadi di satu sekolah, tetapi juga di beberapa sekolah. Dari pengamatan dan observasi yang dilakukan oleh penulis, pada Sekolah Dasar Negeri di Kecamatan Mlati, Sleman, Yogyakarta misalnya masih ditemukan guru yang sering meninggalkan pelajaran untuk mengurus administrasi. Akibatnya siswa menjadi terlantar dan tujuan pembelajaran tidak tercapai dengan maksimal. Selain itu, masih ada guru yang tidak menggunakan Rencana Pelaksanaan Pembelajaran (RPP) ketika mengajar di kelas. Metode yang digunakan tidak bervariasi dan jarang menggunakan media pembelajaran.

Salah satu faktor yang mempengaruhi kinerja guru adalah kepala sekolah (Wibowo, 2014, p.325). Sekolah merupakan sebuah organisasi yang terdapat interaksi dan bekerja sama. Interaksi yang dinamis dan berkualitas antara kepala sekolah, guru, dan tenaga administrasi memainkan peran yang sangat penting dalam kemajuan sekolah. Kepala sekolah harus mampu memberikan layanan yang bermutu dan optimal. Peran kepala sekolah mempunyai pengaruh yang besar terhadap kinerja guru. Moeherione dalam Rahmat dan Kadir (2016, p. 2) menyebutkan bahwa kinerja adalah gambaran mengenai tingkat pencapaian pelaksanaan suatu program kegiatan atau kebijakan dalam mewujudkan sasaran, tujuan, visi, dan misi organisasi yang dituangkan melalui perencanaan strategis suatu organisasi. Sebagai seorang pendidik, guru dituntut untuk mempunyai kinerja yang baik untuk mencapai program yang yang diwujudkan. Kinerja guru dapat dilihat dari beberapa indikator. Pemerintah melalui Undang-Undang No. 14 Tahun 2005 tentang guru dan dosen menyebutkan bahwa kompetensi guru terdiri dari kompetensi paedagogik, kepribadian, sosial, dan profesional. Keempat kompetensi tersebut harus dipahami dan dikembangkan guru sehingga menghasilkan kinerja yang diharapkan.

Dinamika yang harus mendapat perhatian dalam mengembangkan kinerja guru adalah komunikasi. Gouran, Miller, dan Wiethoff dalam Budiono dan Wibowo (2014, p. 150) menyebutkan bahwa komunikasi adalah sebuah pesan yang diproduksi dengan sengaja dan disalurkan oleh 
seseorang kepada satu atau lebih orang lain dengan suatu maksud atau tujuan tertentu. Komunikasi memegang peranan yang penting dalam organisasi sekolah. Pada prakteknya kepala sekolah belum menunjukkan komunikasi yang harmonis dengan para guru. Komunikasi kepala sekolah yang kurang membuat para guru kurang informasi dan menjadi salah paham. Komunikasi merupakan elemen penting yang memiliki fungsi tertentu. Komunikasi yang dilakukan kepala sekolah memiliki fungsi sebagai control (pengendalian), motivating (memotivasi), emotional expression (pengungkapan emosi), dan information (informasi) (Robbins \& Judge, 2015, p. 299). Kepala sekolah mempunyai kewajiban untuk membina komunikasi intern sebaik-baiknya agar para guru mau dan mampu bekerja sama untuk meningkatkan kemampuan dan kinerjanya. Upaya membina komunikasi tidak hanya bertujuan untuk menciptakan kondisi harmonis, tetapi untuk mendapatkan makna yang mendalam dan berarti bagi pendidikan dalam suatu sekolah. Hakekatnya komunikasi yang baik adalah mempunyai pemahaman yang sama antara pemberi dan penerima informasi. Setiap informasi yang diterima sering jauh dari yang disampaikan, sehingga perlu memahami informasi yang disampaikan supaya tidak terjadi kesalahpahaman antar individu.

Sebuah organisasi sekolah tidak jarang terjadi konflik. Menjadi kepala sekolah tidak hanya dituntut untuk mampu berkomunikasi, tetapi juga harus terampil dalam manajemen konflik. Mack dan Synder dalam Anwar (2015, p. 149) menyebutkan bahwa konflik adalah persengketaan antara dua atau lebih pihak yang memperebutkan kedudukan atau sumber melalui tindakan tertentu. Meskipun dalam lingkungan yang kecil, tidak menutup kemungkinan akan menimbulkan konflik. Luthans (2005, p. 391) menyebutkan penyebab konflik secara umum yaitu: 1.) Differences (perbedaan individu); 2.) Information deficiency (kekurangan informasi); 3.) Role incompability (aturan yang tidak sesuai); dan 4.) Environmental stress (lingkungan yang tidak mendukung). Secara umum konflik di sekolah dapat terjadi karena adanya perbedaan latar belakang budaya, adat keluarga, dan pola pendidikan. Seberapa banyak interaksi yang dilakukan oleh beberapa orang di sekolah juga mempengaruhi timbulnya konflik di dalam sekolah meskipun dalam lingkungan yang kecil, hal ini tidak menutup kemungkinan akan menimbulkan konflik apabila tidak memahami satu dengan yang lainnya.

Konflik dapat terjadi kapan saja tanpa dapat diprediksi. Kepala sekolah sebagai pemimpin di instansinya hendaknya memiliki kapasitas dan cara untuk menyelesaikan setiap permasalahan atau konflik yang terjadi di sekolah. Konflik dapat diselesaikan dengan cara keterampilan tertentu seperti: kompetisi (competiting), kolaborasi (collaborating), kompromi (compromising), dan menghindar (avoiding) (Wirawan, 2010, p. 140). Kepala sekolah sebagai pemimpin di sekolah dapat menggunakan kekuasaannya untuk menyelesaikan konflik yang terjadi. Penggunaan keterampilan tersebut tergantung pada waktu dan tempat tertentu. Artinya kepala sekolah dapat menggunakan keterampilan manajemen konflik tersebut sesuai dengan kebutuhan.

Berdasarkan latar belakang tersebut, rumusan masalah yang dapat diambil yaitu seberapa besar kontribusi komunikasi dan keterampilan manajemen konflik kepala sekolah terhadap kinerja guru. Tujuan yang ingin dicapai dalam penelitian ini yaitu untuk mendiskripsikan seberapa besar kontribusi komunikasi dan keterampilan manajemen konflik yang dilakukan kepala sekolah terhadap kinerja guru di Sekolah Dasar (SD) Negeri Kecamatan Mlati, Kabupaten Sleman dalam pengembangan kajian yang berkaitan tentang pendidikan.

\section{METODE}

Jenis penelitian ini termasuk penelitian expost facto dengan menggunakan pendekatan kuantitatif. Penelitian ini bertujuan untuk menggenerelasasikan besarnya variabel-variabel yang di teliti. Penelitian ini dilaksanakan pada bulan April sampai dengan bulan Juli tahun 2017. Penelitian ini dilakukan di seluruh Sekolah Dasar Negeri di wilayah Kecamatan Mlati, Kabupaten Sleman, Daerah Istimewa Yogyakarta. Populasi pada penelitian ini adalah seluruh guru yang berada di SD Negeri Kecamatan Mlati yang berjumlah 321 guru dengan ketentuan: 1.) Berstatus sebagai PNS atau non PNS; 2.) Guru kelas atau mata pelajaran; dan 3.) Memiliki masa kerja minimal dua tahun di lembaga tersebut. Penentuan sampel menggunakan metode tabel Isaac dan Michaels. Sampel responden yang diambil adalah sebanyak 155 responden. 
Teknik pengumpulan data pada penelitian ini menggunakan angket. Setiap responden diberikan angket yang terdiri dari butir-butir pernyataan untuk dijawab. Instrumen tersebut berisi tentang angket kinerja guru, komunikasi kepala sekolah, dan keterampilan manajemen konflik kepala sekolah. Masing-masing pertanyaan mempunyai skala 1-4. Teknik analisis data pada penelitian ini menggunakan regresi sederhana dan regresi ganda. Analisi regersi sederhana digunakan untuk menghitung besar kontribusi variabel komunikasi kepala sekolah (X1) dengan variabel kinerja guru (Y1) dan kontribusi keterampilan manajemen konflik kepala sekolah (X2) terhadap kinerja guru (Y1). Analisis regresi ganda digunakan untuk menghitung kontribusi variabel komunikasi kepala sekolah dan keterampilan manajemen konflik kepala sekolah (X1 dan X2) terhadap kinerja guru (Y1).

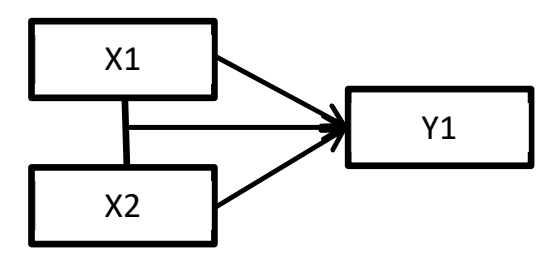

Gambar 1. Desain Penelitian

\section{HASIL DAN PEMBAHASAN}

Uji Hipotesis

Hipotesis pertama pada penelitian ini adalah semakin besar kontribusi komunikasi kepala sekolah maka kinerja guru semakin besar. Hipotesis diterima apabila nilai sig $<0,05$. Hasil perhitungan regresi sederhana yang dilakukan dengan menggunakan software SPSS 21 dapat dilihat pada Tabel 1. Hasil analisis regresi menemukan koefisiensi korelasi (R) sebesar 0,805. Hal ini menunjukkan bahwa terdapat hubungan yang positif antara variabel komunikasi kepala sekolah dengan kinerja guru. Koefisiensi adjusted R2 sebesar 0,646, menunjukkan bahwa komunikasi kepala sekolah menyumbang 64,4\% terhadap kinerja guru. Dapat disimpulkan bahwa komunikasi kepala sekolah mempunyai pengaruh terhadap kinerja guru dan hipotesis semakin besar kontribusi komunikasi kepala sekolah maka kinerja guru semakin besar diterima.

Tabel 1. Rangkuman Hasil Uji Koefisien Determinasi Regresi Sederhana X1 dan Y

\begin{tabular}{ccccc}
\hline Model & $\mathrm{R}$ & $\mathrm{R}$ Square & Adjusted R Square & $\begin{array}{c}\text { Std. Error of the } \\
\text { Estimate }\end{array}$ \\
\hline 1 &, $805 \mathrm{a}$ &, 649 &, 646 & 2,425 \\
\hline
\end{tabular}

a. Predictors: (Constant), Komunikasi Kepala Sekolah

Hipotesis kedua pada penelitian ini adalah semakin besar kontribusi keterampilan manajemen konflik kepala sekolah maka kinerja guru semakin besar. Hipotesis diterima apabila nilai sig $<0,05$. Hasil perhitungan regresi sederhana yang dilakukan dengan software SPSS 21 dapat dilihat pada Tabel 2. Hasil analisis regresi menemukan koefisiensi korelasi (R) sebesar 0,898. Hal ini menunjukkan bahwa ada hubungan yang positif antara variabel komunikasi kepala sekolah dengan kinerja guru. Koefisiensi adjusted R2 sebesar 0,806 menunjukkan bahwa keterampilan manajemen konflik kepala sekolah menyumbang $80,5 \%$ terhadap kinerja guru. Hal ini berarti dapat disimpulkan bahwa keterampilan manajemen konflik kepala sekolah mempunyai pengaruh terhadap kinerja guru dan hipotesis semakin besar kontribusi keterampilan manajemen konflik kepala sekolah maka kinerja guru semakin besar diterima.

Tabel 2. Rangkuman Hasil Uji Koefisien Determinasi Regresi Sederhana X2 dan Y

\begin{tabular}{ccccc}
\hline Model & $\mathrm{R}$ & $\mathrm{R}$ Square & Adjusted R Square & $\begin{array}{c}\text { Std. Error of the } \\
\text { Estimate }\end{array}$ \\
\hline 1 &, $898 \mathrm{a}$ &, 806 &, 805 & 1,802 \\
\hline
\end{tabular}


a. Predictors: (Constant), Komunikasi Kepala Sekolah

Hipotesis ketiga pada penelitian ini adalah semakin besar kontribusi komunikasi dan keterampilan manajemen konflik kepala sekolah, maka kinerja guru semakin besar. Untuk menguji pengaruh komunikasi kepala sekolah dan manajemen konflik digunakan analisis regresi linier berganda. Dalam model analisis regresi linier berganda akan diuji secara simultan (Uji F) dengan ketentuan uji signifikansi 0,05 . Hasil Uji F dapat dilihat pada Tabel 3. Berdasarkan regresi simultan, diperoleh nilai F-hitung sebesar 464,881 dengan probabilitas $(p)=0,000$. Hasil dari perhitungan tersebut diperoleh bahwa komunikasi kepala sekolah dan keterampilan manajemen konflik secara simultan mampu memprediksi perubahan kinerja guru.

Tabel 3. Hasil Uji F

\begin{tabular}{|c|c|c|c|c|c|c|}
\hline & Model & $\begin{array}{c}\text { Sum of } \\
\text { Squares }\end{array}$ & df & Mean Square & $\mathrm{F}$ & Sig. \\
\hline \multirow[t]{3}{*}{1} & Regression & 2201,100 & 2 & 1100,550 & 464,881 &, $000^{\mathrm{b}}$ \\
\hline & Residual & 359,842 & 152 & 2,367 & & \\
\hline & Total & 2560,942 & 154 & & & \\
\hline
\end{tabular}

a. Dependent Variable: Kinerja Guru

b. Predictors: (Constant), Manajemen Konflik, Komunikasi Kepala Sekolah

Tabel 4. Rangkuman Hasil Uji Koefisien Determinasi Regresi Sederhana X1, X2, dan Y

\begin{tabular}{ccccc}
\hline Model & $\mathrm{R}$ & $\mathrm{R}$ Square & Adjusted R Square & $\begin{array}{c}\text { Std. Error of the } \\
\text { Estimate }\end{array}$ \\
\hline 1 &, $927 \mathrm{a}$ &, 859 &, 858 & 1,539 \\
\hline
\end{tabular}

a. Predictors: (Constant), Komunikasi Kepala Sekolah

Berdasarkan pada Tabel 4 dapat diketahui bahwa besar adjusted $r$ square atau kemampuan faktor-faktor komunikasi kepala sekolah (X1) dan manajemen konflik (X2) dalam menjelaskan atau memprediksi variabel kinerja guru (Y) sebesar 0,858 atau 85,8\%. Hal ini berarti, variabel-variabel independen cukup memberikan informasi yang dibutuhkan untuk memprediksi variasi variabel dependennya, dan sisanya $(100 \%-85,8 \%=14,2 \%)$ dijelaskan atau diprediksi oleh faktor lain di luar kedua faktor dan model lain di luar model tersebut.

Tabel 5. Hasil Uji Regresi Linear Ganda

\begin{tabular}{|c|c|c|c|c|c|c|}
\hline & \multirow[t]{2}{*}{ Model } & \multicolumn{2}{|c|}{$\begin{array}{l}\text { Unstandardized } \\
\text { Coefficients }\end{array}$} & \multirow{2}{*}{$\begin{array}{c}\text { Standardized } \\
\text { Coefficients } \\
\text { Beta }\end{array}$} & \multirow[t]{2}{*}{$\mathrm{t}$} & \multirow[t]{2}{*}{ Sig. } \\
\hline & & $\mathrm{B}$ & Std. Error & & & \\
\hline \multirow[t]{3}{*}{1} & (Constant) & 23,998 & 1,357 & & 17,689 & ,000 \\
\hline & Komunikasi Kepala Sekolah & ,318 &, 042 & ,332 & 7,607 &, 000 \\
\hline & Manajemen Konflik & 490 &, 032 & 659 & 15,097 &, 000 \\
\hline
\end{tabular}

a. Dependent Variable: Kinerja Guru

Persamaan regresi yang didapatkan dari hasil perhitungan dapat dilihat pada Tabel 5 . Persamaan regresi yang diperoleh adalah $\mathrm{Y}=23,998+0,318 . \mathrm{X} 1+0,490 \cdot \mathrm{X} 2+\mathrm{e}$, artinya adalah konstanta sebesar 23,998 menyatakan bahwa jika variabel independen nilainya adalah 0 , maka kinerja guru adalah sebesar 23,998. Berdasarkan uji regresi, diperoleh nilai t-hitung sebesar 7,607 koefisien regresi (beta) 0,318 dengan probabilitas $(p)=0,000$. Berdasarkan hasil olah data dimana nilai probabilitas $(\mathrm{p}) \leq 0,05$ dapat disimpulkan bahwa komunikasi kepala sekolah berpengaruh positif dan signifikan terhadap kinerja guru. Berdasarkan uji regresi, diperoleh nilai t-hitung sebesar 15,097 koefisien regresi (beta) 0,490 dengan probabilitas $(p)=0,000$. Berdasarkan hasil olah data dimana nilai probabilitas $(\mathrm{p}) \leq 0,05$ dapat disimpulkan bahwa manajemen konflik berpengaruh positif dan signifikan terhadap kinerja guru. Berdasarkan perhitungan analisis regresi tersebut, maka dapat 
disimpulkan bahwa keterampilan komunikasi dan keterampilan manajemen konflik kepala sekolah mempunyai pengaruh terhadap kinerja guru dan hipotesis semakin besar kontribusi keterampilan manajemen konflik kepala sekolah maka kinerja guru semakin besar diterima.

\section{Kinerja Guru}

Hasil penelitian pada variabel kinerja guru menunjukkan bahwa dari jumlah 23 pertanyaan dengan menggunakan nilai skala 1-4 dan responden 155 orang diperoleh skor tertinggi sebesar 75 , sedangkan skor terendah sebesar 52, dengan nilai rata-rata sebesar 64,02, median 64, modus 64 dan simpangan baku (standar deviasi) sebesar 3,83. Hasil analisis yang dilakukan memberikan informasi bahwa kinerja guru Sekolah Dasar Negeri di Kecamatan Mlati, Kabupaten Sleman, Daerah Istimewa Yogyakarta termasuk dalam kategori sedang, yaitu dengan skor rata-rata 64,02 atau sebesar $71 \%$. Hal ini menunjukkan bahwa kinerja guru di SD Negeri Kecamatan Mlati memiliki kinerja yang cukup baik dalam melakukan tugasnya sebagai guru. Masih kurangnya kinerja guru di SD Negeri Kecamatan Mlati, Kabupaten Sleman, Daerah Istimewa Yogyakarta merupakan akibat dari banyaknya tuntutan yang harus dipenuhi oleh masing-masing guru, salah satunya yaitu masalah administrasi. Para guru sebagian besar masih terperangkap masalah administrasi, seperti pembuatan RPP (Rencana Pelaksanaan Pembelajaran), pemberkasan dokumen di Dinas Pendidikan, serta pemberkasan yang berkaitan dengan perolehan tunjangan-tunjangan. Akibat dari masalah tersebut kinerja guru yang seharusnya dapat mendidik dan membimbing siswa menjadi terabaikan.

Perubahan kurikulum dari Kurikulum Tingkat Satuan Pendidikan (KTSP) ke Kurikulum 2013 juga memberikan dampak pada kinerja guru. Pola yang digunakan pada kurikulum 2013 tentunya berbeda dari kurikulum sebelumnya. Perubahan inilah yang membuat sebagian guru kurang siap dengan kurikulum yang baru, sehingga proses perubahan tersebut akan menghambat kinerja guru. Sebagai guru yang profesional sebaiknya dapat selalu siap dan professional dalam menghadapi segala perubahan, dituntut untuk kreatif dan inovatif dalam melakukan tugasnya. Kinerja seseorang dapat diketahui melalui jumlah pekerjaan, kualitas pekerjaan, ketepatan waktu, kehadiran, dan kemampuan kerja sama (Bangun, 2012, p. 234)

Dalam kasus yang terjadi di SD Negeri Kecamatan Mlati, Kabupaten Sleman, Daerah Istimewa Yogyakarta, masih ditemukan guru yang memiliki kualitas pekerjaan dan ketepatan waktu yang kurang. Hal tersebut dapat dibuktikan dengan adanya perbedaan latar belakang pendidikan yang berbeda dengan bidang yang dilakukan. Masih banyak ditemukan guru yang mengajar di sekolah dengan jurusan yang tidak sesuai. Hal ini membuat kinerja guru menjadi tidak maksimal. Berdasarkan analisis tersebut, kinerja guru SD Negeri di Kecamatan Mlati, Kabupaten Sleman, Daerah Istimewa Yogyakarta masih perlu dioptimalkan agar dalam melaksanakan tugas dan tanggung jawabnya dapat lebih efektif dan efisien sesuai dengan kemampuan dan kompetensi yang dimilikinya. Hal tersebut dapat dilakukan dengan cara mengikuti pendidikan sesuai dengan jurusan yaitu pendidikan sekolah dasar, mengikuti diklat kurikulum yang berlaku, dan mengikuti seminar tentang pendidikan dasar yang berfungsi sebagai pengembangan diri seorang guru.

\section{Komunikasi Kepala Sekolah}

Pada variabel ini menunjukkan bahwa dari jumlah 15 pertanyaan dengan nilai skala 1-4 dan responden 155 orang diperoleh skor tertinggi sebesar 54, skor terendah sebesar 31 . Rata-rata sebesar 44,67, median 45, modus 47, dan simpangan baku (standar deviasi) sebesar 3,83. Komunikasi yang dimiliki oleh kepala sekolah terhadap kinerja guru termasuk kategori sedang, yaitu dengan skor ratarata 44,67 atau sebesar 56,7\%. Hasil tersebut dapat diketahui bahwa komunikasi yang dilakukan kepala sekolah di SD negeri Kecamatan Mlati, Kabupaten Sleman, Daerah Istimewa Yogyakarta cukup baik. Komunikasi dalam organisasi sekolah memegang peranan yang sangat penting. Selain itu, menjadi kepala sekolah merupakan pekerjaan yang membutuhkam komunikasi yang baik supaya terjalin suasana yang harmonis dengan anggotanya.

Beberapa kasus yang terjadi, masih banyak terjadi perselisihan antara kepala sekolah dan guru akibat dari kurangnya kepala sekolah yang komunikatif. Tidak semua kepala sekolah memiliki sifat atau karakter tersebut. Oleh sebab itu, banyak guru yang tidak ingin atau sungkan untuk menjadi kepala sekolah karena tuntutan yang tinggi, padahal banyak sekolah yang kekurangan kepala sekolah 
yang berkompeten dalam menyelesaikan konfik. Kekurangan yang dimiliki kepala sekolah dapat diperbaiki dengan banyak cara, salah satunya adalah dengan memperbaiki cara dan teknik dalam berkomunikasi.

Apabila kepala sekolah memiliki keyakinan bahwa komunikasi yang dilakukan dapat meningkatkan kinerja guru, maka komunikasi tersebut dapat ditingkatkan dengan cara belajar dan bertanya kepada teman yang lebih senior, membaca tentang buku-buku komunikasi, buku manajemen organisasi, dan buku tentang kepemimpinan. Semakin baik komunikasi dan kepemimpinan, maka akan membuat kerja sama sebuah kelompok menjadi semakin bagus (Millar, 2005, p. 22). Sebuah komunikasi merupakan sesuatu yang penting dalam sebuah organisasi. Apabila dilihat dari hasil yang diperoleh, komunikasi yang dilakukan kepala sekolah di SD Negeri Kecamatan Mati, Kabupaten Sleman, Daerah Istimewa Yogyakarta belum mencapai hasil yang maksimal, sehingga dapat berakibat pada kinerja guru. Hasil analisis yang diperoleh dari variabel keterampilan manajemen konflik kepala sekolah SD Negeri di Kecamatan Mlati, Kabupaten Sleman, Daerah Istimewa Yogyakarta termasuk dalam kategori sedang, yaitu dengan skor rata-rata 52,74 atau $60 \%$. Berdasarkan hasil tersebut menunjukkan bahwa kepala sekolah dalam kemampuan mengelola anggotanya belum dapat maksimal, khususnya dalam menangani masalah konflik yang terjadi dalam sekolah.

Kepala sekolah merupakan sebuah jabatan yang kurang diminati. Selain mempunyai tanggung jawab yang besar, kepala sekolah juga harus bisa mengelola konflik dengan baik. Perbedaan sifat individu dalam organisasi sekolah merupakan salah satu penyebab konflik. Beberapa kepala sekolah SD Negeri Kecamatan Mlati, Kabupaten Sleman, Daerah Istimewa Yogyakarta belum memahami masing-masing karakter individu yang ada di sekolah. Akibatnya konflik selalu bermunculan. Salah satu contoh konflik yang sering terjadi adalah banyaknya perbedaan pendapat antara guru dan kepala sekolah dalam memutuskan suatu kebijakan atau strategi dalam mencapai suatu tujuan pendidikan. Ketika kepala sekolah memberikan instruksi, ada guru yang tidak setuju dengan keputusan tersebut, akibatnya dari perbedaan tersebut dapat terjadi konflik. Salah satu penyebab konflik karena ketergantungan pada pekerjaan, perbedaan tujuan, dan perbedaan pendapat (Ivancevich, Konopakse, \& Matteson, 2014, p. 306). Selain itu, ada beberapa kepala sekolah yang belum dapat mengayomi anggotanya dengan baik. Akibat dari hal itu terjadi kelompok-kelompok antar guru maupun guru dengan kepala sekolah. Apabila hal ini tidak dapat ditangani dengan baik, maka akan menurunkan kinerja guru dan iklim organisasi menjadi tidak baik.

Berdasarkan hasil analisis regresi sederhana menunjukkan bahwa pengaruh komunikasi kepala sekolah terhadap kinerja guru ditunjukkan oleh nilai R Square yaitu sebesar 0,649. Artinya, 64,9\% kinerja guru di SD Negeri Kecamatan Mlati, Kabupaten Sleman, Daerah Istimewa Yogyakarta dipengaruhi oleh komunikasi kepala sekolah. Hal ini menunjukkan bahwa strategi komunikasi, dan fungsi komunikasi yang digunakan kepala sekolah SD Negeri di Kecamatan Mlati, Kabupaten Sleman, Daerah Istimewa Yogyakarta masih belum maksimal. Keadaan tersebut belum memberikan kontribusi yang belum signifikan terhadap kinerja guru. Artinya komunikasi kepala sekolah belum memberikan kepuasan kepada guru untuk mengembangkan kemampuan dan kreatifitasnya dalam melaksanakan tugasnya.

Komunikasi yang baik diyakini akan meningkatkan kinerja guru. Berdasarkan perhitungan melalui regresi sederhana, diketahui setiap penambahan satu skor atau nilai komunikasi kepala sekolah, maka kinerja guru akan meningkat. Dengan demikian komunikasi kepala sekolah merupakan faktor yang penting dan harus diperhatikan dalam upaya peningkatan kinerja guru. Implikasi dari hasil penelitian ini bahwa apabila menginginkan kinerja guru yang lebih baik dimasa yang akan datang, maka kepala sekolah sebagai manajer dan pemimpin harus dapat melakukan komunikasi dengan baik dengan melaksanakan proses komunikasi, strategi komunikasi, dan keterampilan berkomunikasi yang tepat dan dalam waktu yang tepat. Dengan demikian kepala sekolah dalam menghadapi permasalahan dapat segera diselesaikan. Selain itu kepala sekolah dapat menjalankan tugas dan aktivitas kepemimpinannya dengan baik.

Terkait dengan hasil perolehan yang berimbas pada kinerja dalam melaksanakan aktivitasnya, fungsi komunikasi kepala sekolah yaitu: 1.) Meningkatkan kemampuan manajerial dan hubungan sosial; 2.) Menyampaikan dan menerima informasi; 3.) Menyampaikan dan menjawab pertanyaan; 4.) Mengubah perilaku melalui perencanaan, pengorganisasian, pengarahan, dan peng- 
awasan; 5.) Mengubah keadaan sosial; 6.) Sarana untuk menyampaikan perintah, pengarahan, pengendalian, pengkoordinasian, pengambilan keputusan, negoisasi, dan pelaporan (Usman, 2013, p. 470). Berdasarkan hasil regresi sederhana kontribusi keterampilan manajemen konflik kepala sekolah memberikan pengaruh sebesar 80,6\%. Determinan tersebut menunjukkan bahwa keterampilan manajemen konflik kepala sekolah SD Negeri di Kecamatan Mlati, Kabupaten Sleman, Daerah Istimewa Yogyakarta mempunyai kontribusi yang cukup signifikan.

Usaha yang dilakukan kepala sekolah untuk memimpin organisasi sekolah memberikan dampak yang positif. Apabila dilihat dari hasil analisis keterampilan manajemen konflik kepala sekolah dengan determinasi mempunyai sedikit perbedaan. Meskipun hasil keterampilan manajemen konflik kepala sekolah mempunyai hasil kategori sedang, namun memberikan dampak yang signifikan terhadap kinerja guru. Hal ini dipengaruhi oleh cara kepala sekolah untuk menyelesaikan konflik dalam organisasi sekolah. Sebagian kepala sekolah belum meggunakan keterampilan manajemen konflik dengan baik bahkan cara mengatasi konflik dilakukan dengan cara yang kurang tepat, padahal banyak faktor di sekolah yang dapat menyebabkan terjadinya konflik. Selain itu, keterampilan kepala sekolah dalam memecahkan konflik juga belum dimiliki. Implikasi dari masalah tersebut adalah kepala sekolah masih perlu dikaji ulang apakah sudah dirasa baik atau perlu ditingkatkan sebagai salah satu faktor yang diperhitungkan. Menurut Luthans (2005, p. 391) penyebab konflik secara umum yaitu: differences (perbedaan), information deficiency (kekurangan informasi yang didapatkan), role incompability (ketidakmampuan dalam bekerja), dan environmental stress (lingkungan kerja yang membuat stess atau lingkungan kerja yang negatif). Suatu konflik tidak dapat diprediksi kapan datangnya, namun perlu kemam-puan yang baik dalam mengelola supaya dapat bermanfaat bagi kepentingan organisasi. Semakin sedikit konflik yang terjadi, maka semakin besar pula tingkat kinerja guru.

Berdasarkan hasil perhitungan regresi ganda terdapat kontribusi yang signifikan dari variabel komunikasi dan keterampilan manajemen konflik kepala sekolah terhadap kinerja guru secara bersama-sama. Hubungan antara komunikasi dan keterampilan manajemen konflik kepala sekolah terhadap kinerja guru diperoleh koefisien korelasi ganda dengan determinasi sebesar $85,8 \%$. Hasil ini menunjukkan bahwa kinerja guru dipengaruhi oleh faktor bagaimana komunikasi dan keterampilan manajemen konflik yang dilakukan kepala sekolah secara bersama-sama. Sedangkan sisanya sebesar $14,2 \%$ dipengaruhi oleh faktor lain yang tidak dikaji dalam penelitian ini. Hasil analisis uji regresi memberikan informasi bahwa setiap peningkatan perubahan terhadap variabel komunikasi dan keterampilan manajemen konflik kepala sekolah terjadi pula peningkatan pada kinerja guru. Hal ini berarti meningkatnya komunikasi kepala sekolah dan keterampilan manajemen konflik kepala sekolah cenderung akan meningkatkan kinerja guru.

Hasil determinasi dari kedua variabel tersebut menunjukkan bahwa pengaruhnya bagi peningkatan kinerja guru begitu signifikan. Apabila kepala sekolah terampil dalam mengengelola konflik dengan keterampilan yang sesuai dan dikombinasikan dengan komunikasi yang baik, maka bukan hal yang sulit untuk menyelesaikan konflik yang terjadi di sekolah, sehingga tidak menurunkan kinerja guru. Terlaksananya komunikasi kepala sekolah yang baik dan efektif memungkinkan para guru merasa tenang dan nyaman dalam melaksanakan aktifitas pembelajarannya, sehingga mengakibatkan kinerja guru menjadi semakin baik. Selain itu, keterampilan berkomunikasi yang baik dapat membantu menangani konflik dengan baik. Namun perlu diketahui juga bahwa kinerja guru tidak saja dipengaruhi oleh komunikasi dan keterampilan manajemen konflik kepala sekolah yang baik, masih terdapat beberapa faktor lain yang mempengaruhinya.

Keterampilan manajemen konflik yang dilaksanakan kepala sekolah dengan melakukan keterampilan penolakan, pengendalian, akomodasi, kompromi, atau kolaborasi tentunya juga dilaksanakan dengan semsetinya agar kinerja guru mengalami peningkatan. Konflik apabila tidak dikelola dengan baik akan menurunkan prestasi kerja dan tentunya akan mempengaruhi aspek organisasi secara keseluruhan. Perlu disadari juga bahwa manajemen konflik dapat menjadi salah satu faktor untuk meningkatkan kinerja guru dalam situasi yang tepat. Hasil ini dapat ditegaskan bahwa komunikasi dan keterampilan manajemen konflik kepala sekolah bukanlah satu-satunya faktor yang mempengaruhi kinerja guru, masih ada faktor-faktor lain yang mempengaruhi peningkatan kinerja guru seperti tingkat pendidikan, pengalaman kerja atau mengajar, keterpenuhan kebutuhan atau gaji, dan faktor lainnya. 


\section{SIMPULAN}

Berdasarkan hasil dan pembahasan yang diperoleh pada penelitian ini, maka dapat ditarik kesimpulan: 1.) Komunikasi kepala sekolah memberikan kontribusi yang positif terhadap kinerja guru di Sekolah Dasar Negeri Kecamatan Mlati, Kabupaten Sleman, Daerah Istimewa Yogyakarta. Artinya semakin baik komunikasi yang dilakukan oleh kepala sekolah, maka kinerja guru akan meningkat. Adapun besarnya kontribusi yang diberikan sebesar adalah sebesar $64,9 \%$; 2.) Keterampilan manajemen konflik kepala sekolah memberikan kontribusi yang positif terhadap kinerja guru di Sekolah Dasar Negeri Kecamatan Mlati, Kabupaten Sleman, Daerah Istimewa Yogyakarta. Artinya semakin terampil kepala sekolah mengelola konflik maka kinerja guru akan meningkat. Adapun besarnya kontribusi yang diberikan adalah sebesar 80,6\%; dan 3.) Komunikasi dan keterampilan manajemen konflik memberikan kontribusi yang positif terhadap kinerja guru di Sekolah Dasar Negeri Kecamatan Mlati, Kabupaten Sleman, Daerah Istimewa Yogyakarta. Artinya semakin terampil kepala sekolah mengelola konflik maka kinerja guru akan meningkat. Adapun besarnya kontribusi yang diberikan adalah sebesar $85,8 \%$..

\section{DAFTAR PUSTAKA}

Anwar, C. (2015). Manajemen konflik untuk menciptakan komunikasi yang efektif (Studi kasus di Departemen Purchasing Pt. Sumi Rubber Indonesia). Interaksi: Jurnal Ilmu Komunikasi, 4(2), 148-157. Doi: https://doi.org/10.14710/interaksi.4.2.148-157

Bangun, W. (2012). Manajemen sumber daya manusia. Jakarta: Erlangga

Budiono, B., \& Wibowo, U. B. (2014). Pengaruh komunikasi organisasi, kecerdasan emosi dan pengambilan keputusan terhadap implementasi peran kepemimpinan kepala SD. Jurnal Akuntabilitas Manajemen Pendidikan, 2(2), 147-158. Doi: https://doi.org/10.21831/amp.v2i2.2445

Ivancevich, J. M., Konopakse, R., \& Matteson, M. T. (2014). Organizational behavior \& management (10th ed.). New York: McGraw-Hill.

Luthans, F. (2005). Organizational behavior (10th ed). New York: McGraw-Hill.

Millar, E. (2005). Training: Performance improvement challenges, the way ahead. Pulp \& paper Canada, 106(10), 28-29.

Pandoyo, R., \& Wuradji, W. (2015). Pengaruh kepemimpinan kepala sekolah, kinerja guru, komite sekolah terhadap keefektifan SDN Se-Kecamatan Mlati. Jurnal Akuntabilitas Manajemen Pendidikan, 3(2), 250-263. Doi: https://doi.org/10.21831/amp.v3i2.6341

Rahmat, A., \& Kadir, S. (2017). Manajemen kepemimpinan dan kemampuan berkomunikasi kepala sekolah pada kinerja pendidik. Jurnal Komunikasi, 8(1), 1-11. Doi: https://doi.org/10.24912/jk.v8i1.43

Robbins, S. P., \& Judge, T. A. (2015). Organizational behavior (16th ed). USA: Pearson Educations.

Usman, H. (2013). Manajemen: Teori, praktik, dan riset pendidikan (4th ed.). Jakarta: Bumi Aksara

Wibowo, W. (2014). Manajemen kinerja. Jakarta: Raja Grafindo Persada.

Wirawan, W. (2010). Konflik dan manajemen konflik: Teori, aplikasi, dan penelitian. Jakarta: Salemba Humanika. 